\title{
THE RISE OF AFRICAN INDEBTEDNESS IN NATAL DURING THE LATE COLONIAL PERIOD
}

\author{
John Lambert
}

In early 1990, the South African government embarked on a process of political change to stifle growing internal unrest and undermine the external sanctions campaign. But, despite removing political measures underpinning apartheid, it has done little about basic socioeconomic problems. The most daunting of these problems is that of poverty, which, in South Africa possibly more than in any other country, reflects the institutionalized inequalities within society. African poverty, in particular, is widespread; the Second Carnegie Inquiry into Poverty and Development in Southern Africa reported that in 198060.5 per cent of Africans were living in poverty. [1] This poverty is not only the manifestation of the great inequalities within society but, to a great extent, results from generations of deliberate official policies.

Impoverishment has gone hand in hand with growing indebtedness. While indebtedness is obviously a symptom of impoverishment, it also contributes to it. In his study of the African poor, John Iliffe distinguishes between the poor, struggling continuously to preserve themselves from physical want, and the very poor who have permanently or temporarily failed in that struggle. [2] By 1910 many Africans in Natal fell into the former category. This paper examines the way in which the insidious growth of indebtedness, as a result of spreading poverty, was drawing many Africans into a situation where, during the twentieth century, they fell into the category of the very poor. To do this, four forms of indebtedness are examined: to money-lenders, farmers, traders and lawyers. The paper ends with an assessment of the Natal government's response to the growing crisis.

Iliffe draws a distinction between the poverty of those with relatively ample resources, especially land, and those who were losing access to such resources and were unable to earn sufficient to meet their minimum needs. [3] In the former situation in Natal, kinship provided the poor with the mechanisms they needed to survive. These included the ukutekela custom. To tekela, literally to beg, enabled members of a homestead whose crops had failed to obtain food from other homesteads. Failure to provide food in such a case was regarded as a serious offence. [4] In addition, the practice of sisa' ing existed for those without cattle: a patron who sisa' $d$ stock was entitled to any increase while the recipient could stave off poverty by using the sisa' $d$ cattle for milk and ploughing.

Although the colonial presence contributed to changes within African society, the state at first did not have the resources to enforce changes, while the primitive nature of settler agriculture ensured the expansion of the homestead economy to supply produce for the market. [5] Although it was impossible in most reserves for Africans to cultivate more than a small proportion of their land, a majority lived on white-owned farms. Until the late $1870 \mathrm{~s}$, the labour and rental demands of the settlers did not seriously affect the homestead economy. At the same time, with few fences, and with so much land owned by speculators or the Crown, Africans in even the most inhospitable parts of Natal could graze their cattle and make gardens elsewhere. These conditions did, however, mean there was little need for most Africans to adapt their methods of agriculture to cope with the demands of the colonial market.

The market economy did, however, lead to restratification within African society. Homesteads near markets were well placed to accumulate wealth, while homestead heads with a special relationship with their chiefs were better able to profit than were less 
favoured men. Therefore, even in geographically advantageous areas, not all Africans could respond equally. For some the market economy could have meant impoverishment.

In the 1880 s, the expansion of settler agriculture began placing restrictions on African access to land and resources, both on farms and in the reserves. With less land at their disposal, the quality of herds and of harvested crops declined. Competition for resources, particularly in the reserves, became widespread with an increasing number of Africans becoming impoverished as they fell behind in the competition.

The slide into poverty also owed much to the series of ecological disasters which hit Natal from the late 1880s. Droughts, locusts, rinderpest and East Coast fever played havoc with the homestead economy. The impact of rinderpest was particularly devastating and rebuilding herds was painfully slow. Under these circumstances the stratification between rich and poor became even more marked with the latter having few resources to rebuild their herds or to cultivate sufficient grain. The widespread destruction of herds meant that the sisa system, which had ensured the survival of those with few resources, virtually ceased to function and Africans turned to men such as traders for cattle, thus further undermining the socio-economic relationships underpining African society. The disasters also saw a growing number of Africans dependent on purchases of grain to feed themselves. With limited financial resources, they either offered labour to farmers in return for maize or turned to traders for credit.

The impact of these disasters was magnified both by the confiscation of cattle after the Bambatha rebellion and by demands for higher rentals (up to $£ 10$ a hut) and increased labour. Inadequate grain harvests and the destruction of herds undermined the tenants' ability to pay the increased rentals and the number being sued for non-payment grew. In cases where judgement was given against the tenant and he was unable to pay, cattle were usually attached, often of a value far in excess of the amount owed. Debtors who had insufficient stock were imprisoned, often more than once for the same debt. [6] On lands where farmers' labour requirements were growing, tenants had their grazing and gardens restricted [7], while the conditions under which they had to provide labour from their homesteads for six months each year were tightened, leaving them little opportunity to cultivate their gardens. [8]

Bill Freund points out that "production in Africa cannot be divorced from questions of power and inequality". [9] That this is true for late-colonial Natal is evident from the changing balance of power within the settler community. Until the $1880 \mathrm{~s}$, the colonial administration had followed a broad policy of support for the homestead economy and had tended to resist farming pressure for legislation which would have undermined it. By the late $1880 \mathrm{~s}$, and particularly after 1893 when Natal received responsible government, this attitude changed and policies were adopted which were detrimental to African independence and which reflected notions of white supremacy. A dominant settler consciousness which stressed ethnic differences between white and black was beginning to develop. The result was the elaboration of a theory of black ethnic inferiority which was believed both to explain growing African impoverishment and to give legitimacy to the placing of legal restrictions on Africans.

These restrictions were aimed primarily at destroying the homestead economy's competitiveness with white production. Legislation was introduced to protect the farmers' interests and to meet their demands for land and labour. The most important was the Native Servants' Identification Act of 1901 (and its 1903 amendment) which established a system of registration and of passes for labourers in Natal. [10] A farmer had to endorse his tenant's pass with the period he was allowed to leave the farm, placing the latter in the absolute power of the farmer who could refuse to endorse the pass. [11]

A proliferation of laws affecting Africans led to anger and despair, feelings well summed up by Mbovu: "Government is expanding every few years. The Government resembles Tshaka, for he never got tired. Its army is money." [12] And, indeed, these years saw a great 
increase in the amount Africans had to contribute to the colonial revenue, culminating in 1905 in the levying of a poll tax of $£ 1$ on all unmarried male adults in the colony. [13] In the same year a correspondent lamented in Ilanga that the "strings of one's money bag will remain loose now and be ever ready to shake out all that is in it for taxation". [14]

The cumulative effects of taxation, legislation and disasters were making it difficult for most homesteads to support their members without the young men going out to work. In addition to farm work and labour in the towns, there was a growing demand for labour from industries, and particularly from the Transvaal gold mines. Although the colonial authorities were determined that the needs of the mines should not interfere with the colony's own labour requirements, migrant labour to the Witwatersrand was becoming an important source of homestead revenue. Yet migrant labour contributed to a spiralling situation. In the knowledge that money from labour would be available to buy grain, many homesteads raised the money needed for rentals and taxes (usually due between April and June, after the harvesting), by selling most of their maize crop at a time when prices were low. [15] When, towards the end of the season they had to buy grain to feed themselves, prices were high [16] and they had to borrow from farmers, traders or money-lenders.

\section{Usurious Interest}

The problem of indebtedness was compounded by the difficulties Africans experienced obtaining either credit or loans at the prevailing colonial rates. Few Africans other than owners of land were able to offer collateral, and this excluded all but a small minority. Although the prevailing rate was 6 per cent, there was no legal limit placed on interest and African borrowers were required to pay high, usually usurious rates. There was a growing disquiet at the blatant injustices involved in the system, and in 1905 the Smythe ministry asked magistrates for information. [17]

The information revealed both a widespread system of usury and an appalling lack of official concern. Although promissory notes had to be signed in front of a magistrate, few enquired about the interest charged. According to the magistrate of Umvoti: "I witness hundreds each year - they disclose neither ... how much interest or how much money lent." He was prepared to accept this despite being aware of the very high rates charged. [18]

Conditions in Stanger, a centre of Indian money-lending, were particularly notorious. [19] In their work on Indian traders, Padayachee and Morrell refer to the lack of information on money-lenders because the informal nature of much of their business precluded the keeping of records. [20] The magistrate of Mapumulo referred, however, to a case which had attracted sufficient notoriety to come to his attention: Uhayi kaGudu, Mboza kaGudu and Macala kaMalamula had borrowed £7.10.0. from Amod M Mather of Stanger and were required to repay $£ 20$ after one month. This represents interest per annum of 320 per cent. Being unable to do so they borrowed the money from a second Stanger money-lender, A E Jackson, and were required to pay a further $£ 8$ interest. [21] This was an extreme case, and in general 60 per cent per annum seems to have been the average interest charged to African borrowers. [22] Cases of money being advanced at between 600 and 800 per cent were common, however, with the borrower often having to surrender crops and stock to pay the interest. [23]

\section{Indebtedness to Farmers}

Indebtedness amongst farm tenants appears to have been particularly widespread, in part reflecting the problems faced by their landlords. The first decade of the twentieth century was a difficult time for most white agriculturalists in Natal. Recession, drought and cattle disease militated against improvements and the credit which had been available in the 1890s 
was drying up. As a result, the prosperity enjoyed by successful dairy and beef farmers and by wattle and sugar planters did not filter through to those less enterprising men who made up the bulk of the settler farming community. For many farmers, and this also includes Kholwa such as Stephen Mini, the most remunerative form of farming remained squeezing as much labour and rental out of their tenants as they could. [24]

Coping with difficulty themselves, few were concerned at the lot of their tenants. In 1908, the South African Native Races Committee pointed out that labour tenants were generally underpaid and miserably housed and fed. [25] As they were often unable to work off the farm to meet their financial needs, they were obliged to borrow from their landlords and to agree to pay back in labour, tying them into a cycle of indebtedness. As Robinson, a member of the Legislative Assembly, commented, "I think that in a great many cases these Natives for a long number of years remain practically slaves to their employers, and at the finish of their employment they have practically nothing". [26] This situation was exacerbated by the fact that many farmers demanded that the loan be repaid by a period of service in excess of the amount borrowed. [27]

It is difficult to know how usurious this system was for few farmers kept records of such loans, and even fewer drew up promissory notes. According to Maurice Evans, a member of the Legislative Assembly, the usual rate closely followed that of the average interest charged to Africans by money-lenders, that is, $1 \mathrm{~s}$. per $£ 1$ per month, or 60 per cent. [28] But in cases where promissory notes were issued, it was not necessarily to the advantage of the tenant. If he was unable to pay by the due date and was taken to court, a new loan would have to cover, necessitating another promissory note. [29] In 1907 Malkoba was taken to court by his landlord, Henry Callaway Gold of Ixopo division, over an unpaid loan, and borrowed to pay the fine. [30] Farmers generally took their tenants to court as a last resort, however, and preferred dealing with them in their own way.

Henry Gold was one of the few farmers whose diaries have survived. Between 1898 and 1910 , they mention numerous loans to his tenants for which he usually expected labour in return. Only one entry mentions the period - Jacili received $£ 3$ for which he had to work for six months without pay, that is he had to repay it at a rate of $10 \mathrm{~s}$. wages per month. The diaries mention two instances of loans to be repaid by cash: in 1904 Umwaqaya received $£ 2.10$ s.0d. and had to pay interest of 10 s. per fortnight (48 per cent p.a.) while in 1909 Hebegi had to pay $£ 3$ within two months for a $£ 2$ loan ( 300 per cent). [31]

\section{Indebtedness to Traders}

Although reserve inhabitants were not faced with the same conditions as those on the farms, many were becoming caught up in a similar situation of indebtedness. In need of money for food and taxes, they turned to their local traders for advances.

Because of their agricultural techniques and monoculture, African producers were more affected by conditions such as drought than were white farmers. As has been mentioned, taxes were normally payable after the harvest when prices were low. To meet these demands, many Africans were selling crops they needed for their own consumption and were later buying maize at higher prices. This - and a growing demand for imported goods - was changing African attitudes. As the trader was now the supplier of their needs, it was easy to become dependent on him for food instead of, as in the past, relying on traditional methods of exchange and barter. Evidence of traders taking advantage of African misfortune is widespread and is reflected in an increase in the number of promissory notes they were drawing up. [32]

The need to rebuild cattle herds ensnared the Africans even further into a system of debt. This need coincided with a concerted campaign by the Transvaal gold mines to recruit labour throughout southern Africa by means of labour agents, or touts. Initially, chiefs and izinduna 
were contracted to supply labour [33], but, as the mines developed and a greater supply of labour was needed, so the mining houses turned increasingly to traders.

Traders offered an ideal source of supply, for in the rural areas they had direct access to the homesteads, the inhabitants of many of which were already becoming dependent on them. Both Horwitz and Beinart have shown that traders throughout southern Africa were able to offer cash advances to labourers, while many built up cattle herds in order to have beasts to offer as advances for labour. [34] Men in need of money or of cattle for lobola would contract with a trader, agreeing to serve on the mines for a specific period at a nominal wage in return for an advance of up to $£ 20$, or for one or two head of cattle which had to be repaid at at least double the value. As a result they received hardly any monthly pay and sank further into debt [35], while there was little risk involved to the trader for the homestead head was responsible for repayment. [36] The 1906 Native Affairs Commission was told that nine out of ten African labourers were working off advances. [37]

\section{Indebtedness to Lawyers}

In its report, the 1906 Commission also drew attention to the spreading indebtedness resulting from the increasing number of court cases involving Africans.

The advent of responsible government in 1893 heralded the introduction of a wide array of laws making Africans liable to a wide range of fines. The result was a dramatic increase in the number of Africans appearing in court. [38] In 1906 Joseph Baynes pointed out that an average of 4,000 Africans were arrested every month for breaches of laws, regulations and municipal by-laws. [39] A large proportion of those charged were convicted; between 1903 and $1905,129,772$ were charged of whom 99,678 , or 76.8 per cent, were convicted. [40] Of these, many contracted debts to pay the fines and escape imprisonment. [41]

Court rules and regulations introduced during the 1890 s made it more difficult for Africans to conduct their own cases. [42] In addition, the use of contracts, promissory notes, bonds, mortgages and the ownership of immovable property had become widespread and had made the use of lawyers necessary. In Klip River County, in particular, where land purchases were by syndicates, which the law did not recognize as a purchaser, there were numerous problems concerning individual rights. The result was "endless and costly litigation". [43]

Evidence given to the Native Suitors' Commission of 1902 also reveals the extent to which Africans were using lawyers to protect themselves from the exactions of both chiefs and farmers. Dhlozela's words sum up much of the evidence: "lawyers are the pillars that support the world, and from whom we get our salvation because they assist the person who is being skinned by the very chiefs ..."; and, "If we have no lawyer to assist us every white man on the farm will be his own lawyer". [44] The former comment is indicative of the breakdown occurring in hierarchical relations within the kinship system and explains why, despite the charges levied by lawyers, so many of the commoners who gave evidence in 1902 welcomed their services. A large proportion of the work of country lawyers was for African clients [45], who, between 1901 and 1905, were represented in court in $25 \%$ of all cases. [46] Some of these were quite unnecessary: for example, a lawyer seldom charged less than $£ 2$ to $£ 3$ a case yet, in Upper Tugela, Boya retained G Jackson when he sued Alexander Brothers for 12s. for transport charges. [47]

The payment of lawyers' fees was causing privation and hardship. Many debts were incurred to collect sufficient to pay the costs. These frequently led to further civil actions for recovery [48], which in turn often led to the defendants' property being seized to pay judgement and costs. [49] As confiscated stock was almost invariably given a low valuation, the high price of cattle after rinderpest would have involved people in heavy losses and contributed to the further spread of indebtedness in the colony. 


\section{The Response of the Natal Administration}

In 1906, Africans in Natal and Zululand rose in rebellion. Despite acting ruthlessly against the rebels, the government could not but be aware that many Africans had been driven into rebellion by a growing sense of despair at the economic pressures placed on them. This realization led to the appointment in 1906 of the Natal Native Affairs Commission, with particular instructions to enquire into the charging of usurious rates to Afrficans by moneylenders, farmers and traders. No mention was made of indebtedness to lawyers.

The Commission received many complaints about usury, revealing a "lamentable condition of affairs, showing the extent to which cupidity can go in trading upon the weakness and necessities of others". [50] In their report, the commissioners recommended, inter alia:

a. That loans for interest should not be recoverable unless upon an attested written document; that ... no higher rate than fifteen per cent per annum be recovered upon any action, the courts having power at the same time to inquire into all the circumstances of the loan.

b. That every promissory note ... should specify the amount borrowed, the rate of interest agreed .... and the date of repayment. [51]

The new Moor ministry accepted these recommendations and in August 1907 instructed magistrates, until legislation was enacted, to carry them out when attesting promissory notes and to refuse to attest them if usurious charges were made. [52]

Despite the urgency of addressing the problem of usury, a Native Interest Bill was introduced into the Legislative Assembly only in July 1908, and enacted later that year. Under the Act, the rate of interest and the date of repayment had to be stipulated in the promissory note, and the terms of a loan had to be explained to the borrower by a magistrate or justice of the peace. Fifteen per cent was laid down as the maximum interest which could be charged. Although this was higher than the colonial average of 6 per cent, few Africans were in a position to offer adequate security for the lower rate.

The speeches in Hansard dealing with money-lenders bristle with righteous indignation. As so many money-lenders were Indians, it was easy to be indignant; the tone was very different when dealing with farmers who advanced money. The 1906 report described the giving of advances to be repaid by labour as the "most usual form of money-lending", recommended that it be included in the proposed interest bill, and suggested that the terms of repayment be the subject of contract and should not be enforceable under the Masters and Servants Act. [53] Although the Native Interest Bill included these recommendations, they were deleted by the Prime Minister, Frederick Moor, during the second reading. In attempting to justify this deference to farming opinion, Moor argued that to include the selling of labour for loans would bring about "a great hardship on the Native population, and also on many of the employers of labour". Ignoring the stranglehold the pass system placed on labour tenants, he averred that "unlike the interest the Native knows exactly what his labour is worth". [54]

Indebtedness of farm tenants was, as has been seen, compounded by the abuse by farmers of the Identification Pass system. The commissioners recommended that the system be abolished and commented that it "is not an over-statement of the case to say that the position contains the germs of much unrest, and, by reason of its immensity and importance, warrants and demands the intervention of the state". [55] Their recommendations for an improvement of the conditions of labour tenants were ignored by the ministry, indicative of the continuing hold of the farming community over the administration. 
In their report, the commissioners urged that the abuses inherent in the advance system used by traders be ended. They recommended that store debts should not be recoverable against a homestead head unless it had been incurred personally by him, or by his authority. [56] They further recommended that Africans should receive the full wage for their labour, and that if advances were made to them they should not be at a higher rate than 15 per cent per annum. Contracts for advances should be signed in front of a magistrate. [57] The ministry ignored these recommendations as well.

In a further attempt to eliminate the abuses inherent in touting, the Secretary for Native Affairs, Arthur Shepstone, and one of the four District Native Commissioners, Chere Emmett, visited Johannesburg in 1909 to investigate conditions on the mines. In their report they commented:

\begin{abstract}
We find that it has been customary for mining houses to place their contracts for the supply of native labour in the hands of contractors of native labour in Johannesburg. These "middlemen" ... and their agents have no more than a monetary interest in natives recruited by them ... [and] have no compunction in making all they can out of the natives whose value to them is calculated by the length of the period for which they are willing to give their labour ... [They are] private individuals who are engaged in recruiting solely for speculative reasons. In some cases we find that natives have passed through the hands of almost a dozen labour agents, and native runners, all of whom share the recruiting premiums paid by companies by which they are eventually employed, which premiums are subsequently recovered from the natives. [58]
\end{abstract}

The Shepstone-Emmett report proposed that, in order to minimize the abuse of advances, the Transvaal government should establish depots in suitable districts in Natal and Zululand through which they could obtain labourers with as little recourse as possible to touts. [59] They also recommended that, when labourers were recruited by touts, no advance exceeding $£ 5$ be permitted. [60] No action appears, however, to have been taken on these recommendations.

\title{
Conclusion
}

By the end of the colonial period, despite the acknowledgement by the Native Affairs Commission that the despair arising out of indebtedness had played a major part in the outbreak of the Bambatha Rebellion, little had been done to remedy the evil. While usurious rates had been limited to 15 per cent and more effective checks had been introduced to protect African borrowers from money-lenders, nothing had been done to alleviate the causes which led to indebtedness in the first place. As a result, as the need for loans remained as great as ever, many Africans found themselves in a position where they were forced into illicit borrowing and obviously the risk involved in this form of illegal transaction ensured very high interest rates.

In addition, the most common cause of indebtedness, that arising from loans to secure labour, had deliberately been ignored by the Moor ministry. Attempts to limit advances paid by traders to Africans going to the gold mines were quietly ignored while the ministry made no secret of its determination to resist any attempt to interfere with farmers' relations with their tenants.

By Union, African indebtedness accordingly remained widespread throughout Natal. On one level, it can be argued that it had become a mechanism which could be used to ensure the survival of those homesteads which were in the process of losing access to cattle and which 
were incapable of cultivating sufficient to feed themselves. The disruption of the precolonial support system meant that without loans many homesteads might have been unable to survive and the process of proletarianization which occurred later in the century might have been hastened. Loans, however, merely delayed the process while the indebtedness which resulted from them ensured that many of the poor of late-colonial Natal, struggling to preserve themselves from physical want, were, in the post-Union period, to fall into the category of the very poor.

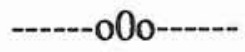

Notes

1 F Wilson and M Ramphele, Uprooting Poverty: the South African challenge (Cape Town, 1989), p 17.

2 J Iliffe, The African Poor: a history (Cambridge, 1987), p 2.

$3 \quad$ Ibid., p 4.

4 L H Samuelson, Zululand: its traditions, legends, customs and folklore (new ed, Durban, 1974), p 180; Interview with R T Mazibuko, Inanda, 8 August 1979.

5 H Slater, "The Changing Pattern of Economic Relationships in Rural Natal, 18381914", in S Marks and A Atmore (eds), Economy and Society in Pre-Industrial South Africa (London, 1980), p 148.

6 Natal Land and Colonisation Company (NL \& C), (Natal Archives) 220, No 71, Walton and Tatham to General Manager, Durban, 14 December 1895.

7 Ibid., No 159, Baynes to General Manager, Durban, 22 Januatry 1886; C J Smythe Papers (Killie Campbell Library), Regulations for native tenants, 31 August 1896.

8 M S Evans, Black and White in South East Africa: a study in sociology (London, 1916), p 136.

9 B Freund, The African Worker (Cambridge, 1988), p 3.

10 Legislative Assembly (LA) Hansard, XXX, 27 June 1901, SNA, pp 459-60.

11 SNA 1/1/460,. 1121/1910, Minutes of meetings held at magistrates' offices in No 2 District, Howick, 18 March 1910.

12 C de B Webb and J BWright (eds), The James Stuart Archive of Recorded Oral Evidence Relating to the History of the Zulu and Neighbouring Peoples

(Pietermaritzburg, 1982), 3, Mbovu, 8 February 1904, p 29.

13 Act 48, 1903, To amend the Squatters' Rent Law of 1884; Natal, Report ... Native Population, 1904, p vii; Act 38, 1905, To impose a poll tax.

14 SNA, 1/1/329, 2966/05, Ilanga translation, 3 November 1905.

15 See Natal Blue Books (NBB), 1895, pp 41, 45. 
16 LA, Hansard, XXXVI, 2 June 1904, SNA, p 499; SANAC, 3, Chairman of the Chamber of Commerce, $\mathrm{p} 435$.

17 SNA, 1/1/349, 2823/06, Circular 126/1905, 21 September 1905.

18 Ibid., Magistrate Umvoti to PUS, 5 October 1905.

19 SNA, 1/1/2, Minutes of Council for Native Affairs, 12 August 1909.

20 V Padayachee and R Morrell, "Indian Traders in the Natal Economy, c1875-1914", University of Natal, Pietermaritzburg, History Workshop, Natal in the Precolonial and Colonial Periods, 24-25 October 1990, p 16.

21 SNA, 1/1/349, 2823/06, Circular 126/1905, Magisțrate Mapumulo to PUS, 24 October 1905.

22 Ibid., Bergville Magistrate to PUS, 2 October 1905.

23 Ibid.

24 Natal Agricultural Journal, VI, No 12, 10 July 1903, p 422; VIII, No 9, 22 September 1905, p 965; X, No 7, 26 July 1907, p 735; XIII, No 4, 29 October 1909, p 532. For the reference to Mini, see S Meintjes, "The Ambiguities of Ideological Change: the impact of settler hegemony on the AmaKholwa in the 1880s and 1890s", University of Natal, Conference on the History of Natal and Zululand, 1985, p 23.

25 South African Native Races Committee, The South African Natives: their progress and present condition (London, 1908), p 13.

26 LA, Hansard, XLIV, Robinson, 2 July 1908, p 248.

27 Ibid., Evans, p 249.

28 Ibid., p 248.

29 Ibid., Greene, p 250.

30 Henry Callaway Gold Papers (Killie Campbell Library), KCM 89/17/11, Diary, 12 June 1907.

31 Henry Callaway Gold Papers, KCM 89/17/13, Diary, 7 April 1909; KCM 89/17/8, Diary, 22 June 1904; KCM 89/17/13, Diary, 8 February 1909.

32 NBB Departmental Reports, 1884, p B16; SNA, 1/4/ 3, c17/86, SNA to magistrates, 5 November 1886.

33 Natal Advertiser, 19 July 1887, advertisement by Joseph Pascoe.

34 R Horwitz, The Political Economy of South Africa (New York, 1967), p 24; see also W Beinart, The Political Economy of Pondoland, 1860-1930 (Cambridge, 1982), pp 56-58.

35 SNA, $1 / 1 / 446,3283 / 09$, The Touts Act: how it affects labour.

36 Natal, Report of the Native Affairs Commission, 1906-7 (Pietermaritzburg, 1907), p 32. 
37 Natal, Native Affairs Commission, 1906-7, Evidence (Pietermaritzburg, 1907), Chairman, p 767.

38 Natal, Department of Native Affairs, Annual Report, 1902.

39 J Baynes, Letters addressed to His Excellency the Governor of Natal and His Majesty's Secretary of State for the Colonies regarding the absence of consideration in our present form of government for our coloured population (Pietermaritzburg, 1906), pp 10, 22.

40 Natal, Department of Native Affairs, Annual Report, 1903-05.

41 Natal, Report of the Native Affairs Commission, 1906-7, p 32.

42 CSO, 2811, Native Suitors' Commission, Evidencé, G Hulett, p 810, Matiwane, p 917.

43 Natal, Report ... Native population, 1898, p B11; see also Natal, Native Suitors' Commission, 1902, Report, p 24.

44 CSO, 2811, Native Suitors' Commission, Evidence, Waller, p 575.

45 Ibid., 2811, Waller, p 575.

46 Natal, Department of Native Affairs, Annual Report, 1905, p 170.

47 Upper Tugela Magistracy (Natal Archives), 2/1/1/1/1, 16/92, Boya v Alexander Brothers.

48 Natal, Native Suitors' Commission, 1902, Report, USNA minority report, p 25.

49 See Upper Tugela Magistracy, 2/1/1/1/3, Civil records.

50 Natal, Report of Native Affairs' Commission, 1906-7, p 31.

51 Ibid., p 32.

52 GH, 1275, Enclosure in despatch 111, Governor to' Secretary of State, 14 June 1908 USNA to magistrates, 21 August 1907, p 59.

53 Natal, Report of the Native Affairs' Commission, 1906-7, pp 31-32.

54 LA, Hansard, XLIV, Prime Minister, 2 July 1908, pp 246-47.

55 Natal, Report of the Native Affairs' Commission, 1906-7, pp 27-28.

56 Ibid., p 32.

57 Ibid., p 36.

58 GH, 1278, Enclosure 1 of despatch 197, SNA, and District Native Commissioner to Prime Minister, 7 November 1909, pp 163-64.

$59 \mathrm{GH}, 1236$, No 197, Governor to Secretary of State, 12 November 1909, p 359.

$60 \mathrm{GH}, 1278$, Enclosure 1 of despatch 197, SNA, and District Native Commissioner to Prime Minister, 7 November 1909, p 166. 